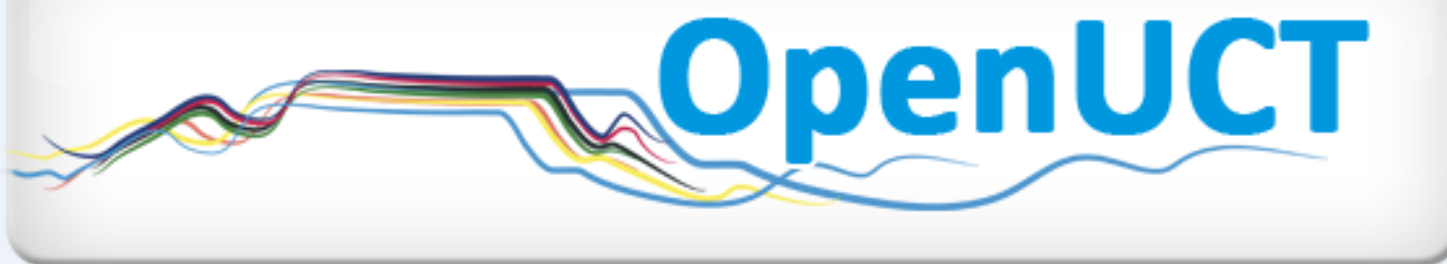

This is the author-approved manuscript version of a journal article published in:

Paxton, M. 2007. Tensions between textbook pedagogy and the literacy practices of the disciplinary community: a study of writing in first year economics. Journal of English for Academic Purposes. 6: 109-125. DOI: 10.1016/j.jeap.2007.04.003.

It is made available under the terms of agreement between the author and the journal, and in accordance with the University of Cape Town's Open Access Policy for the purposes of research, teaching and private study. http://www.openuct.uct.ac.za/sites/default/files/UCTOpenAccessPolicy.pdf 


\title{
Tensions between textbook pedagogy and the literacy practices of the disciplinary community: A study of writing in first year economics
}

\author{
Moragh Paxton \\ Academic Development Programme, Centre for Higher Education Development, University of Cape \\ Town, Private Bag Rondebosch 7701, South Africa \\ E-mail address: mpaxton@ched.uct.ac.za.
}

\begin{abstract}
Moragh Paxton is Co-ordinator of the Language Development Group in the Centre for Higher Education Development at the University of Cape Town. She has experience designing and teaching access level academic literacy courses and postgraduate language education courses as well as in staff and curriculum development.
\end{abstract}

\begin{abstract}
This paper describes aspects of a research project which used linguistic and intertextual analysis of student writing to investigate the relationship between the academic curriculum and student voice in a first year economics course at a South African university. I argue that the discourses and practices of first year university economics textbooks provide a model of literacy practices which contradict many of the literacy practices of the discipline of economics. The first year economics textbook in particular, rather than exposing students to a variety of arguments and encouraging the development of critical reading skills appropriate for academic contexts, tends to be single voiced. This gives the impression of consensus in the discipline and it may encourage rote learning and plagiarism. This argument is supported with data from a research project.
\end{abstract}

Keywords: Textbook; Economics; Academic literacy; Plagiarism; English for academic purposes; Academic writing

\section{Introduction}

This paper argues that the economics textbook, the main genre to which students are exposed in their undergraduate studies is not an appropriate model for learning the specialised literacy practices of the disciplinary community and that it may also encourage plagiarism. The paper draws on data from a larger research project (Paxton, 2003, 2004, 
2006) which used linguistic and intertextual analysis to investigate the intersection of the academic curriculum and student voices in first year economics assignments at the University of Cape Town (UCT). The findings of this research project highlighted the many and varied conflicts students encounter as newcomers to the practices and discourses of university economics, but, in this paper, I will focus particularly on the difficulties a diverse group of students from the larger case study had with the two first year economics textbooks used on the course, i.e., McConnell and Brue (1999) and Mohr and Fourie (2000). These difficulties are challenging enough for first language speakers of English but speakers of English as an additional language (EAL) from rural South African schools have an even greater struggle. The paper will begin by describing the theoretical and methodological insights used to frame the research, before going on to illustrate, by means of excerpts from assignments and interview data the ways in which students misinterpreted information in the textbook and plagiarised from it.

Textbooks play a very central role in economics, a role similar to that of textbooks in the sciences. The textbook is constantly referred to in economics lectures and tutorials and students are generally expected to have read the relevant sections of the textbook before they come to the lecture. In many first year courses only one textbook is set and it may be the only reading required for the course, therefore textbooks are often the only reading material that first year students encounter.

Hyland (2000, p. 105) distinguishes the discourse of the university textbook from disciplinary discourses by pointing out that it is a pedagogic discourse which uses what he describes as metadiscourse 1 to guide the reading process. Textbooks define the discipline presenting the principle concepts and analytical methods of the discipline. However, as Brown (1993, p. 65) indicates, in order to do this the discourse becomes "canonised" which means the multitude of past, contesting voices are presented as a single voice. In this way textbooks differ from other academic genres such as the research articlez where research findings are presented, new claims made and theories disputed. In the research article, writers try to persuade the disciplinary community to accept their claims and certify them as recognised and legitimate knowledge, therefore claims need to be located within a wider disciplinary framework and other contributions to the field need to be formally acknowledged.

The difficulty for students lies in the fact that textbooks not only present the knowledge and values of the discipline, they also provide students with the first exemplar of the literacy practices of the new discipline. But the monologic nature of textbook writing does not prepare students for other economics texts they will encounter, neither does it demonstrate the ways in which academic writers weave their own voices through a multiplicity of other acknowledged voices.

In the analysis of student writing that formed part of my study (Paxton, 2004), I found a range of diverse discourses from the African oral and narrative traditions, the church, the television and the internet interlaced with the more academic discourses. However, there were also many instances of students simply regurgitating information from the textbook without properly understanding it because they found the language of the textbook 
inaccessible and because of the powerful authoritative role that the textbook plays in first year courses such as economics. If students borrow too closely from the textbook they block out their prior discourses and thus fail to integrate the new knowledge into existing knowledge structures.

\section{Theoretical framework}

The basic assumption underlying my study is that language and literacy are social practices which vary according to social context, therefore literacy takes on different forms and functions in different social settings. In the study I use a post-structuralist notion of 'discourse' to describe the accepted ways of "saying-doing-being-valuing-believing" (Gee, 1996, p. 127) that characterise a particular social context.

Thus in the university there are many different discourses and many different ways of "saying-doing-being-valuing-believing." When students begin their academic studies they have to appropriate a variety of these very specialised academic discourses, and this has been shown to be a complex process (Ballard \& Clanchy, 1988; Bartholomae, 1985; Johns, 1997; Lea \& Street, 2000; Paxton, 2004). However, as Hyland (2000) indicates, becoming competent in the social practices of a particular discipline is crucial for successful membership in the discourse community.

Studies (Gee, 1996; Heath, 1983) show that middle class urban literacy practices acquired in the home (i.e., primary discourses) coincide with those taught in school and at university (secondary discourses), while other literacy practices do not; this means that schooling creates inequalities and can lead to low attainment of certain groups in the educational context. Gough (2000) emphasises that this does not mean that other cultures do not have secondary discourses, but rather that secondary discourses in other cultures such as the rhetoric employed in various ceremonies or in traditional legal discourse in Xhosa culture may be very different from secondary discourses of the Western world such as academic discourse. Gough and Gee point out that acquiring academic literacy/essay text literacy is not so much about learning a secondary discourse as being apprenticed to Western rhetorical norms.

My research sought to move away from the deficit model of student literacy and to consider the complexity of acquiring academic literacy for a range of students from different backgrounds. The aim was to analyse students' literacy practices to gain a more in depth understanding of them and to acknowledge that these varied practices, while they may be inappropriate in economics, are valued and completely logical in their relevant settings. If we set out to simply replace these student discourses with the authoritative discourse of the textbook, we lose the richness of cultural understanding and skills that the students bring with them. Whereas if we acknowledge the rich repertoires they draw on and encourage students to refine and build on them, they provide the groundwork for further development. This seems particularly important if one considers that changes in a person's discourse patterns as they acquire a new form of literacy involve a change in identity which may conflict with the person's initial acculturation and socialisation (Heath, 1983; Scollon \& Scollon, 1981). Students entering the university experience these conflicts as they start to become members of the discourses of the university and to take on new social identities, finding that their other social worlds are juxtaposed with the academic world (Clark \& Ivanıc, 1998). 
One of the keys to providing better access to these academic discourses is to make the practices of the discipline explicit (Ballard \& Clanchy, 1988; Gee, 1996). However, discipline specialists seldom do this because the culture is so intuitive to them and because making beliefs and values explicit is not easy; "it means objectifying our own culture, making a deliberate act of imaginative and intellectual disengagement" (Ballard \& Clanchy, 1988, p. 13). If the literacy practices of the discipline are not made explicit, this leads to gaps between teacher expectations and student interpretations of certain tasks and activities. For instance, the need for referencing and the penalties of plagiarism may repeatedly be stressed in lectures and departmental handbooks, and yet students will continue to plagiarise because accessing a new and very foreign discourse is a slow and very complex process and because students need a careful induction into the literacy practices of the discipline.

\section{Economics and the economics textbook}

As language tutor in economics I had worked with the economics department for a number of years to design an adjunct module in Language and Communications to support students' essay writing processes through the first year of studying economics. This allowed me to develop an understanding of the epistemology and methodology of the discipline and gave me insights into the ways disciplinary specialists understand the role of reading and writing, the process of discourse acquisition and the role of the textbook.

Economics seems to straddle the boundaries of hard vs. soft 3 and pure vs. applied dimensions of academic disciplines (Becher \& Trowler, 2001). It started out as a predominantly soft discipline but, after the Second World War, it began to aspire to the scientific standards of physics, because it was felt that objectivity and mathematical precision would give greater scope and credibility to the discipline. Since then economics has become more strongly theory-orientated and mathematically sophisticated and thus 'harder' (Becher \& Trowler, 2001; Henderson, Dudley-Evans \& Backhouse, 1993). This scientific methodology has been reflected in economics by the use of modelling as a method of presenting ideas in economics. Mason (1990), in an analysis of an economics textbook, shows how this abstract method is matched by abstract language such as the use of nominalisation, metaphor, personification, syntactic features like the passive and the leaving of gaps in the message in presenting the economics model.

Economics textbooks were not included in Hyland's extensive analysis of 56 textbooks in eight different disciplines (2000). However, it is probably true to say that introductory economics textbooks are similar to physics, chemistry and biology textbooks at the first year level and often define the discipline for first year students. Hyland's research is important because it points to the role textbooks play in introducing the novice to the epistemology of the new discipline. In order to illustrate the ways in which textbook writers guide their readers, Hyland focuses on metadiscourse, and finds that the overwhelming dominance of textual forms (particularly in the sciences) seems to confirm that metadiscourse is used to guide the reading process and to assist the instructional role of the genre (2000, p. 114). In Hyland's study, he found that the science and engineering texts showed less concern with elaborating an explicit interpersonal context for negotiating meaning. 
Henderson, Dudley-Evans, and Backhouse (1993) explore a range of issues relating to the language and rhetoric of economics. Although most of the articles in this volume focus on the discourse of research articles, rather than that of the undergraduate textbook, Brown (1993), in the same volume, does provide a useful analysis of textbook discourse, using Bakthin's notion of canonisation to describe the discursive process by which the range of historical voices constituting economic thought lose their heterogeneity and become reduced to a single voiced, unified discourse (1993, p. 70). Brown points out that Bakhtin's distinction between monologic and dialogic discourse is better understood as one of degree and type rather than as an absolute one. Brown says that the first year economics textbook could be seen as the canon, a prime exemplar of monologic discourse and would be situated at the extreme of this continuum.

In his specific focus on the economic discourse of the textbook, Klamer (1990) observes that economics textbooks present a well-balanced ideological and methodological picture of the discipline. This is done in order to simplify and avoid confusion but also, as Klamer observes, to "convey the impression of consensus among economists, of a discipline that meets the standards of a hard science" (1990, p. 131). He finds the rhetoric of the economics textbook problematic because it is not acknowledged that the 'facts' of the textbook derive from research based on different assumptions and resulting in different economics models. In reading the textbook, students get no sense of the ways in which economic researchers conduct their inquiries, or that economics "involves the art of argument and that disagreement is the spice of economic discourse" (Klamer, 1990, p. 152).

Textbooks achieve this consensual view "by their scientistic employment of graphs and equations; their avoidance of uncertainty and controversy; and ... by their longevity"

(Swales, 1993, p. 223). Myers (1992, quoted in Swales, 1993, p. 224) points to the "absence of hedging, the paucity of references to the primary literature... the wide use of the present tense" as some of the techniques chosen by textbook writers to convince their readers of the certainty of what they are describing. Discussing elementary textbooks in the sciences, Myers (1992) says that textbooks reify and codify statements as facts, that statements do not find their way into textbooks because they are facts, but rather, a statement is taken as a fact because it is in the textbook.

\section{Illustrations of rhetorical techniques in economics textbooks}

As I have indicated, the economics textbooks we have used recently in microeconomics at UCT, i.e., McConnell and Brue (1999, 2000, 2005) and Mohr and Fourie (2000), have many of the same features as science textbooks. Particularly notable are the ways in which economic textbook practices differ from the referencing conventions and practices of the disciplinary community. Textbooks make very little use of references to the primary sources, usually have no bibliography and little or no in-text referencing. Nevertheless, textbook authors draw on a wide variety of outside sources and borrow the values and beliefs of other writers as they construct their texts.

In order to illustrate the referencing practices of the first year textbook, I will do a brief analysis of an excerpt from McConnell and Brue (1999, p. 703). I use this illustration to 
foreground the difficulties that the students had with this textbook and with a South African textbook, Mohr and Fourie (2000).

\section{Example 1.}

Causes of Growing Inequality

Growing U.S. income inequality in the past three decades has attracted the attention of many scholars, who have suggested three major interrelated explanations.

1. Greater demand for highly skilled workers

Perhaps the most significant contributor to growing income inequality has been an increasing demand for workers who are highly skilled and well educated. Many firms have restructured their production methods in ways which require more highly skilled, better-educated workers. Also, several industries requiring highly skilled workers have recently emerged or expanded greatly such as computer software development, business consulting, biotechnology, healthcare, and advanced communications systems. Because highly skilled workers remain relatively scarce, their wages have been bid up, so the wage differences between them and less skilled workers have increased. Since 1980 the wage difference between college graduates and high school graduates has risen from 37 to 66 percent for women and from 34 to 60 percent for men. One study found that workers who use computers earn 10 to 15 percent more than similar workers who do not... (McConnell \& Brue, 1999, p. 703)

In the first line of this excerpt, the research identifying the three major causes of inequality in the U.S. is broadly acknowledged, however the 'scholars' involved in this research remain nameless; there is no formal recognition of their contribution. The excerpt then draws on statistical information without indicating what the sources of this information are. Again, the author refers to an anonymous 'study' that was done showing that workers who use computers earn more than those who do not. This kind of simplification aims to make the text more readable and accessible, however, the single voicedness is problematic for novice readers for two reasons.

Firstly, the reader is given the impression that these are 'facts,' rather than the perspectives of particular authors. The passage above shows how textbook writers have developed quite skilful rhetorical strategies to convey the idea that the entire economics profession shares these beliefs and therefore there is no need to use conventional referencing practices.

Secondly, the extract shows that economic textbook referencing practices are very different from those of the disciplinary community which are exemplified by the use of footnoting or the Harvard method in scholarly articles in economics. If textbooks are the only models of the literacy practices of the discipline that undergraduate students encounter, students may get the impression that the textbook is an appropriate model for them to follow and that they should regurgitate the 'facts' from the textbook without acknowledging them.

\section{Methodology}

My study (Paxton, 2004) focused on an interpretive qualitative analysis of the three coursework essays in a first year economics course, ECO100A, to explore the shifts and changes that take place over the first academic year as students appropriate the new 
discourse. Essay writing data from the eight students in the case study 5 was collected, categorised and analysed and then students were interviewed after each essay so that they could act as 'expert witnesses' (Herrington \& Curtis, 2000) to assist in the interpretation and analysis of their writing. This larger study accumulated an extensive amount of data from the eight case study students and some of this data illustrates a heavy reliance on the textbook in the early stages of essay writing. However, in an article of this length I am unable to present a full analysis of this data, therefore, I will draw on selected interview data and extracts from essays of just four students from very different socio-economics backgrounds.

The data was drawn from an adjunct literacy module which we have introduced into the first year extended course in microeconomics. In this Language and Communications module students are introduced to the academic literacy practices of the discipline of economics and are prepared for the writing of three economics essays. The essays are set by the economics lecturers and marked jointly by the language tutors and the lecturers in the microeconomics course. In preparation for the first essay, students were required to draw on a limited number of set readings, including the textbook. Before they wrote the essay they had been introduced to the Harvard method of referencing in a double period workshop and taught how to acknowledge quotes and ideas from other authors. Students were taught the what, when, how and why of citation practices and they were made aware of the rules and regulations relating to plagiarism.

In analysing my data, I used the framework Fairclough (1989) developed for analysing the relationship between a linguistic text and wider social processes. In addition to a description of text, Fairclough calls for an interpretation of the social processes that give rise to the production and interpretation of the text as well as an explanation of the social historical conditions within which participants are situated. This forms his three-part model for discourse analysis and it falls under the broader description of critical discourse analysis (CDA). I have used this model of CDA to analyse students' hybrid 'interim' literaciess in order to uncover acquisition processes and to illustrate both the barriers and resources that contribute to learning. Thus I focused in some detail on the students' social and economic backgrounds and also on the new academic context to which they wish to gain access. This enhanced my understanding of the outer or explanatory layer of Fairclough's model and my analysis of student writing then moved back and forth between all three layers of the model illustrating how the model works.

Interpretive qualitative studies such as this one are often criticised because they are not generalisable. But Davis (1995) points out that the strength of this type of study is that it allows for an in depth understanding of what is specific to a particular group. In addition, qualitative studies establish 'grounded theory' (Glaser \& Strauss, 1967) through the process of analysing data and this grounded theory potentially allows for transfer to a wide range of social situations. Thus my findings may offer insights which are helpful to literacy teachers working in a variety of similar contexts across the curriculum. Davis (1995) suggests that when a study provides this kind of 'thick description,' the reader is intended to become a co-analyst of the data and interpretations presented. In addition the research may raise a range of questions with the potential for further research. 


\section{Background of students}

In this section I will present brief biographies of the four students from the case study whose writing I will focus on in this article. These biographies provide insights into the students' socio-economic backgrounds and thus contribute to the outer explanatory layer of the Fairclough model. Section 3 of this article (Economics and the economics textbook) has provided information on the academic context, and contributed further to this explanatory layer.

The extended course in microeconomics, ECO100A, attracts a diversity of students who may not have met the requirements to be admitted to the mainstream microeconomics course. Ayanda is a Xhosa speaker who grew up in Khayelitsha during the turbulent eighties when townships around Cape Town were torn apart by the violence and upheavals associated with the latter years of apartheid. He attended a township school and was the only student from his school to be accepted at UCT in 2001. In the later years of schooling there was no accounting teacher at his school and so the students taught themselves. $\mathrm{He}$ studied English as a second language at school and experienced a lot of difficulty with English at university, as the following comment from an interview shows:

I often feel disadvantaged because I feel uncomfortable when I speak English in front of many people, like in lectures because I am not fluent enough.

Nomsa is a Zulu-speaker from a township school outside Durban and her schooling experiences were similar to those of Ayanda. She said her schooling had not prepared her well for university, particularly in relation to the literacy and numeracy skills that were required. She confided that, although, theoretically, English had been the medium of instruction at her school, most of her subjects had been taught in Zulu. Both Ayanda's and Nomsa's mothers were single parents earning a pittance as domestic workers in more affluent suburban homes. Although the students received financial aid bursaries from the National Student Financial Aid Scheme to enable them to study at UCT, they struggled to pay the small annual family contribution of US $\$ 500$ required by the scheme at this time.

Sherry has had to deal with all the frustrations and complexities that students from mixed race origins often experience in South Africa. Her family was one of those who experienced forced removals from their homes and communities under the apartheid Group Areas Act. Thus, she has grown up in Gugulethu, one of the outlying poorer townships of Cape Town. However, she regards English as her first language and she has enjoyed the benefits of better schooling because her parents made many sacrifices to enable them to send her to one of the former Model $C_{7}$ girls' schools in the suburbs of Cape Town. Philip, is also English speaking but he is white and from a middle class background; he attended one of the elite former Model $\mathrm{C}$ boys' schools in Cape Town.

\section{Data analysis}

In the first part of this analysis I would like to present data which illustrates how the textbook's use of unmodified assertions was sometimes misleading, particularly for the EAL students, and led to misinterpretation of information. In the second part I will focus on the way students copied very closely from the textbook in the writing of their first essay. 
I use my interviews with the students to assist my analysis of their written data and to shed light on the middle layer of the Fairclough model, i.e., the processes of production and interpretation of text.

\section{Misinterpretation of the textbook}

The students' confusion around legal patents in the essay on monopolies provides a good illustration of how the textbook was misinterpreted. Three students mentioned that a legal patent for producing beer had been awarded to the monopolist, South African Breweries (SAB), by the government. The tutors who marked this essay commented in feedback, that this was incorrect and queried the source of the information. The extract from Ayanda's essay is quoted below and the marker has commented "But NOT the case here" because there are no patents in the beer industry in South Africa:

Patent laws also [act] as block to entry of potential brewers in the beer market. SAB is the first producer of beer in SA, so other potential brewers that are willing to enter this industry by being attracted by the profits that $S A B$ make or they want to be competitive, they have to be patient, because patent laws take sometime before allowing entry for new brewers to the beer industry, a monopolist is given the [patent] by government to dominate and enjoy its invention fruitfully up until a specified period of time (McConnell and Brue, 1999).

Ayanda has referenced the textbook, McConnell and Brue (1999), while Nomsa told me in her interview that she had found the information on patents in the textbook. The extract from Nomsa's essay is quoted below:

SAB can also be described as a monopoly because it has the sole right of producing beer in South Africa. The government has issued SAB the patent right over breweries in South Africa, the purpose is to eliminate competition in the market.

I realised, when I looked up the section on legal patents, that it was the 'canonised' discourse of the textbook that had misled students into assuming that patents applied to all monopolies. McConnell and Brue (1999) included patents or legal barriers in their discussion of barriers to entry, but the authors never explicitly indicated that legal patents were not awarded to all monopoly firms. I have reproduced this extract below to illustrate how the use of unmodified assertions, achieved through rhetorical devices such as an absence of hedging and use of the present and future tenses (underlined in the extract), might give students the impression that patents were universal and applied to all monopoly firms. This is an American textbook, and examples of American modern day giants, such as General Electric, that have been awarded patents might also lead students to assume that South Africa's modern day giant, SAB, would have a patent:

\section{Barriers to Entry}

The factors that prohibit firms from entering an industry are called barriers to entry. In pure monopoly, strong barriers to entry effectively block all competition.

\section{Legal Barriers to Entry: Patents and Licenses}

Government also creates legal barriers to entry by awarding patents and licenses. 
Patents $A$ patent is the exclusive right of an inventor to use, or to allow another to use, her or his invention. Patents and patent laws protect the inventor from rivals who would use the invention without having shared in the effort and expense of developing it. At the same time, patents provide the inventor with a monopoly position for the life of the patent. The world's nations have agreed on a uniform patent length of 20 years from the time of application. Patents have figured prominently in the growth of modern day giants such as IBM, Merck, Kodak, Xerox, Polaroid, General Electric and DuPont. (McConnell \& Brue, 2000, p. 465)

Ayanda felt that he had justified his argument for South African Breweries' patent by indicating that SAB was the first producer of beer in South Africa and therefore he sees it as 'the inventor' of beer and deserving of a patent. In the textbook extract quoted above there seems to be an assumption on the part of the text book writers that their readers would know that not all monopoly firms invent new products and that they are not all awarded patents. However, when books are written for such a diverse audience, the authors cannot afford to make too many assumptions about students' background knowledge. In this instance, the certitude with which the 'facts' are presented has misled the students and the textbook has failed to get its message across. A textbook only communicates effectively when the writer has correctly assessed the reader's resources for interpreting it.

\section{Echoing the textbook}

As the brief biographical data illustrates, students came from very different schooling backgrounds and their experiences of writing at school differed vastly. Nomsa was a student in the Commerce faculty and this was her first exposure to writing from multiple sources, whereas Sherry and Philip were Humanities students and were learning these skills in their other courses such as history and philosophy. Yet all three students had difficulty manipulating the language of the textbook in order to paraphrase and establish their own voices in their writing.

Although the way the students referenced was mostly incorrect, they certainly seemed to be trying to practise the new conventions they had learned. However I found that many of the students were drawing extensively on the textbook, sticking very closely to the wording of the textbook and their own voices seemed to be hidden. Often what students indicated to be paraphrases by providing the reference, but no quotation marks, are actually almost identical to sections of the original text. The Chambers dictionary definition of a paraphrase is "the expression of the same thing in other words" and in a good paraphrase, one would expect to see the same discourse style but a different choice of lexis and syntactic arrangement. Below, the extracts from Nomsa's and Sherry's essays are juxtaposed with the extracts from the textbook, Mohr and Fourie (2000), to illustrate the ways they have copied:

\section{Extract One}

According to P. Mohr and L. Fourie. 2000; market system characterised by individualism, private freedom, private property, property right and also decentralised decision making. There limited government intervention [sic]. (Nomsa)

Usually this type of market system would be characterised by: individualism, private freedom, property rights, decentralised decision-making (P. Mohr and L. Fourie, 
Economics for South African Students. Pretoria: J. L. van Schaik Publishers, pp. 45-47) (Sherry).

Such an economic system is characterised by individualism, private freedom, private property, property rights, decentralised decision making and limited government intervention. (Mohr \& Fourie, 2000, p. 47)

\section{Extract Two}

Because according to the three basic questions as to what to produce? how to produce? And to whom to produce? The answer is those goods and services that consumers are willing to spend their income on and which can be supplied profitably (P. Mohr and L. Fourie; Economics for South African students 2d ed (2000) [sic] (Nomsa).

What will be produced in a market system? The answer is those goods and services that consumers are willing to spend their income on and which can be supplied profitably (Mohr \& Fourie, 2000, p. 47).

Nomsa has copied the long list of nominal phrases directly from the textbook rather than paraphrasing. In Extract Two, the sentence Nomsa has copied as answer to her three questions, only answers the first question 'what to produce?' This is an indication that she was copying without fully understanding the words she had borrowed. The above example of 'borrowing' may be an indication that the students have assessed the context and the audience for which they are writing and recognised what is valued in that context. My interviews with the students provide further insights into the text production process (i.e., Fairclough's middle layer). In the following extract from my interview with Nomsa she seems to be indicating that she regards economics textbook discourse as an 'authoritative discourse' (Bakhtin, 1981):

Interviewer: Why didn't you use the information that was in your head rather than what was in the book?

Nomsa: I thought this information was true.

In Sherry's interview she shows she has a similar sense of the textbook discourse as 'authoritative':

I always make it a point that whenever I read something from a textbook that I try to write it ... how can I say... to emulate what they say.

Bakhtin's notion of authoritative discourses is useful for understanding the way students copy the words of the textbook. He cites religious, political and moral texts as examples of authoritative texts. He says this sort of text "demands our unconditional allegiance"; it does not weave in with other voices and social languages, but rather,

...[it] enters our verbal consciousness as a compact and indivisible mass; one must either totally affirm it, or totally reject it. It is indissolubly fused with its authority with political power, an institution, a person - and it stands or falls together with that authority. One cannot divide it up - agree with one part, accept but not completely another part, reject utterly a third part. (1981, pp. 342-343) 
Philip was more successful in establishing his own voice in the introduction to his first essay (paragraph 1), but then, by inserting a long list of unconnected, repetitive and poorly paraphrased excerpts from one textbook he seems to borrow a voice that is not yet his own and his writing loses coherence. The first part of his essay follows:

Before starting with the main argument, I think we need to understand what a market actually is. 'A market is any contact or communication between potential buyers and potential sellers of a good or service'. (Mohr and Fourie, 2000, p. 45) (1)

Any firm or mechanism which connects potential buyers and prospective sellers of certain goods and services is thought to be a market. (Mohr and Fourie, 2000) (2)

For a market to exist, there are certain conditions which have to be followed such as:

1. there must be not less than one potential buyer and seller of a good or service,

2. the seller should have a good or service to sell,

3. the buyer must have a suitable method to purchase a good or service,

4. a means of exchange or market price must be determined,

5. the agreement must be guaranteed by law or by a particular tradition (Mohr and Fourie, 2000) (3).

Philip's essay gives the appearance of a patchwork of definitions from the textbook, with occasional attempts at paraphrasing. The essay loses coherence because he fails to establish links between the definitions. Paragraph (2) and the first point in paragraph (3) are really redundant. They add nothing to the reader's understanding of a market because they simply repeat the definition offered in paragraph (1).

Asked why he had reproduced the format (numbered points) and wording of the textbook, Philip said:

I just find that with Economics - you have to be very specific in the way you answer your questions... with some of the other courses like Philosophy and history for example you can thumbsuck a little bit.

When the interviewer asked if being specific meant drawing on the textbook, he said:

I think you do sort of stuff...stuff like that... in most of my essay I usually have maybe a paragraph or two where I combine a lot of stuff which actually comes... maybe if I'm late or if I'm stuck... but I take all that stuff that I've read and I kind of put it into my own understanding.

Philip's comment that "you have to be very specific" in economics shows insight into the new discourse and is confirmed by applied linguistics research which indicates that the hard knowledge areas value "succinctness and precision" (Hyland, 1999, p. 109). Students writing in economics are expected to employ the 'compressed code' of the discourse and provide more finely detailed explanations of issues than they would be required to do in some of the other social sciences. The implication is also that in order to be 'specific' and show that he has appropriated the discourse, he has to adhere very closely to the original textbook discourse.

From the interview it is difficult to establish whether Philip repeats the notion of connecting potential buyers and sellers because he has not understood the meaning of the 
textbook extracts or whether, as the second excerpt from his interview suggests, he simply had not bothered to edit for repetition because the essay was written in haste.

\section{Explanation}

An explanation for students' reluctance to tamper with authoritative voices seems to lie in the notion of the textbook as 'fact.' Students get the impression that the textbook contains immutable facts which are not to be questioned or debated. The canonised discourse of the economics textbook provides no sense of the historical development of economic thought; instead the multiple and contesting voices of economic theorists have been smoothed out, erased, so that statements become reified as fact. Students may be concerned that by changing the wording, they may change the meaning of the 'facts.' This would be true particularly for second language students who feel they don't have the language to express the ideas of the source text accurately. They see the language as rigid and foreign, something they are not able to alter and put in their own words.

In interviews the students said that at school, teachers had either given them notes from the textbook or encouraged them to make their own notes by copying or paraphrasing from the textbook. They explained that in economics essays at school they had been taught to define all economic terms and simply regurgitate the facts from the textbook in any order. Kapp's (2001, p. 243) research into the former Department of Education and Training (DET) township schools in Cape Town describes this as the 'thirty marks for thirty facts' phenomenon and confirms it as the dominant practice. Therefore using economics textbooks for reading and writing practices in first-year university classrooms may, in the South African context, simply build on traditions of rote learning established in the former apartheid schools and perpetuate some of the practices that students have brought with them from school.

Borrowing or copying from source texts can take a variety of forms and the excerpts above have illustrated some of these. In some cases, these would be described as 'plagiarism' by the university authorities. And yet what is happening in these student essays seems far more complex than plagiarism. As Ivanıc says, it is very difficult to draw the lines between plagiarism, imitation and acquiring the discourse (1997, p. 195). Much recent research (Angelil-Carter, 2000; Bartholomae, 1985; Hull \& Rose, 1990) and indicates that students learn to write like academics by attempting to mimic the style of academics. Hull and Rose describe it as "trying on" the discourse; they say that: “...human beings continually appropriate each other's language to establish group membership, to grow and to define themselves in new ways" (1990, p. 242). Sticking closely to the textbook seems to illustrate that powerful social forces, such as the need to conform and to appropriate the discourse, influence the choices students make about which discourses to draw on.

I recognise that it is important that students go through this transitional phase where they 'try on,' copy and practise the new discourse, in order to make it their own and to define themselves as academic writers. However, it is important that students are equipped to move on from this phase. Therefore, my particular focus in this discussion goes beyond the contentious issue of plagiarism and punishment to a concern for what copying means for student learning and for development of student writing. In the excerpt from Nomsa's 
essay I pointed out that she may not have understood the sentences that she was copying from the textbook. If students fail to understand what they copy, it seems unlikely that they will ever make the ideas 'their own.' Learning is an interactive process rather than a one-way transfer of knowledge and some of the findings of my research illustrated the ways in which students built on their prior discourses and practices in order to conceptualise and to learn new ways of writing. For instance, in another part of Nomsa's essay she used her own phrase "boss of the market" for the concept of 'consumer sovereignty,' a reconstruction which a tutor had assisted her with by explaining that consumer sovereignty meant that the consumer was 'king' of the market. Nomsa's personal reconstruction triggered important associations and situated meanings for her which allowed a transformation of understanding and an appropriation of meaning. In time and with further feedback from the tutor she will become more comfortable using the correct term. By then she would truly have 'acquired' the concept and understood what it meant.

It is clear from the discussion so far that the features of the textbook genre have an important impact on the processes of interpretation and text production. When students copy and paste from the textbook they are blocking out prior discourses and other sources of knowledge in an attempt to sound like the textbook and this means that they are not building on prior knowledge and experience in order to make sense of the new. Students are acquiring a large amount of information in the form of definitions in piecemeal fashion and don't integrate the new learning into existing knowledge structures.

The aim of the textbook writer is to make the textbook easier to understand. Hyland (2000) points out that the first year textbook conveys the key ideas and analytical methods of the discipline. However, textbooks not only present the knowledge and values of the discipline, they also provide students with the first exemplar of the literacy practices of the discipline. This is problematic because the monologic nature of textbook writing does not prepare students for other economics texts they may have to read. Neither does it foster critical reading.

Moreover, students learn how to write academic arguments by reading well-structured models of economics writing, and by understanding how knowledge is constructed and contested. Therefore if students have only ever been exposed to the canonised discourse of the economics textbook, they may have difficulty learning to present an argument in an economics essay. If they have had no good models to demonstrate the multi-voiced nature of texts, they will tend to mimic the textbook and may have little sense of how to weave together and acknowledge the voices of different authorities in their academic essays. This could mean that students are locked into being 'interim' producers of the discourse and prevented from becoming full members of the disciplinary community or recognised as independent knowledge makers. If the textbook leaves students with an understanding of economics as a coherent canon, how are they being prepared to go on to postgraduate studies where they will be expected to critique and contest different perspectives?

\section{Conclusion}

In this article I have illustrated the difficulties students were having with the first year economics textbook by drawing on extracts from students' essays. The essay writing data was further illuminated by excerpts from interviews in which students assisted in the interpretation and explanation of their writing. I have shown how some of the techniques used by textbook writers to convince readers of the certainty of what they are describing 
may run the risk of being misinterpreted. In addition I have argued that the first year economics textbook, rather than exposing students to a variety of arguments and encouraging the development of critical reading skills appropriate for academic contexts, tends to be single-voiced which gives the impression of consensus in the discipline and may encourage rote learning and direct copying from the textbook. This suggests that the discourses and practices of first year university economics textbooks provide a model of literacy practices which contradict many of the literacy practices of the discipline of economics.

As I have indicated, students in the extended course in microeconomics worked on three essays through the academic year and I attempted to address some of the complexities outlined above through a systematic programme to address academic writing in the curriculum. In designing the Language and Communications module in economics I had to find a way through the inherent tensions of developing students as critical readers with a sense of the contested nature of economic thought, while at the same time, equipping them to be academically literate and successful so that they 'take on' the discourse of economics.

Initially, the students were introduced to genres beyond the textbook to illustrate the multi-voiced nature of texts. This provided an opportunity to contrast the textbook genre with other genres, pointing out rhetorical strategies used by textbook authors to simplify and produce monologic discourse. In addition students were taught to analyse the different voices within their readings so that they learnt to locate authors within a framework of ideas and realised that knowledge is not absolute and that ideas belong to different traditions. Students were provided with models of academic argument and they learnt how to draw on evidence from different sources to support an argument and how to position themselves in relation to other authoritative voices. The drafting and rewriting process allowed an opportunity for feedback and revision and a consolidation of some of these skills. The data from the third and final essay showed that the students' writing had developed steadily and slowly through the academic year. They had a better grasp of how to reference other sources and of how to establish their own voices in their texts. They also seemed to be more comfortable expressing ideas in their own words rather than borrowing the words of the textbook. The study, therefore, seems to indicate that all students, but particularly those from historically disadvantaged schools in South Africa, need to be explicitly taught the literate behaviours and given opportunities to try out the very complex practices of the discipline.

\section{Acknowledgements}

The financial assistance of the Spencer Foundation and the University of Cape Town University Research Committee is gratefully acknowledged.

\section{References}

Angelil-Carter, S. (2000). Stolen language? Plagiarism in writing. Harlow: Pearson Education Limited and Longman.

Bakhtin, M. M. (1981). The dialogic imagination (M. Holquist, Ed., Trans.). Austin, Texas: University of Texas Press.

Ballard, B., \& Clanchy, J. (1988). Literacy in the university: An 'anthropological' approach. In G. Taylor, B. Ballard, V. Beasley, H. Bock, J. Clanchy, \& P. Nightingale (Eds.), Literacy by degrees (pp. 7-23). Milton Keynes: Society for Research into Higher Education \& Open University Press. 
Bartholomae, D. (1985). Inventing the university. In M. Rose (Ed.), When a writer can't write (pp. 34-165). New York: Guildford Press.

Becher, T., \& Trowler, P. (2001). Academic tribes and territories (2nd ed.). Buckingham: Society for Research into Higher Education and Open University Press.

Bloor, M., \& Bloor, T. (1993). How economists modify propositions. In W. Henderson, T. Dudley-Evans, \& R. Backhouse (Eds.), Economics and language (pp. 153-169). London: Routledge.

Brown, V. (1993). Decanonizing discourses: Textual analysis and the history of economic thought. In T. Dudley Evans, W. Henderson, \& R. Backhouse (Eds.), Economics and language (pp. 64-84). London: Routledge.

Clark, R., \& Ivanı c, R. (1998). The politics of writing. London: Routledge.

Fairclough, N. (1989). Language and power. London: Longman.

Davis, K. (1995). Qualitative theory and methods in applied linguistics research. TESOL Quarterly, 29(3), 427-453.

Gee, J. (1996). Social linguistics and literacies: Ideology in discourses (2nd ed.). London: Routledge/Falmer.

Glaser, B., \& Strauss, A. L. (1967). The discovery of grounded theory. Chicago: Aldine.

Gough, D. (2000). Discourse and students' experience of higher education. In B. Leibowitz, \& Y. Mohamed (Eds.), Routes to writing in South Africa (pp. 43-58). Cape Town, South Africa: Silk Road International Publishers.

Heath, S. B. (1983). Ways with words: Language, life and work in communities and classrooms. Cambridge: Cambridge University Press.

Henderson, W., Dudley-Evans, T., \& Backhouse, R. (Eds.). (1993). Economics and language. London: Routledge.

Herrington, A. J., \& Curtis, M. (2000). Persons in process: Four stories of writing and personal development in college. Urbana, IL: National Council of Teachers of English (NCTE).

Hull, G., \& Rose, M. (1990). Toward a social-cognitive understanding of problematic reading and writing. In A. A. Lunsford, H. Moglen, \& J. Slevin (Eds.), The right to literacy (pp. 236-244). New York: The Modern Language Association of America.

Hyland, K. (1999). Disciplinary discourses: Writer stance in research articles. In C. Candlin, \& K. Hyland (Eds.), Writing: Texts, processes and practices (pp. 99-121). London: Longman.

Hyland, K. (2000). Disciplinary discourses: Social interactions in academic writing. Harlow: Pearson Education Limited.

Ivanı c, R. (1997). Writing and identity: The discoursal construction of identity in academic writing. Amsterdam: John Benjamin.

Johns, A. M. (1997). Text, role and context: Developing academic literacies. Cambridge: Cambridge University Press.

Kapp, R. (2001). The politics of English: A study of classroom discourses in a township school. Unpublished doctoral dissertation, University of Cape Town, South Africa.

Klamer, A. (1990). The textbook presentation of economics discourse. In W. J. Samuels (Ed.), Economics as discourse: An analysis of the language of economists (pp. 129-154). Boston: Kluwer Academic.

Lea, M., \& Street, B. (2000). Student writing and staff feedback in higher education: An academic literacies approach. In M. Lea, \& B. Stierer (Eds.), Student writing in higher education: New contexts (pp. 32-46). Buckingham: The Society for Research in Higher Education and Open University Press.

Mason, M. (1990). Dancing on air: Analysis of a passage from an economics textbook. In W. Henderson, T. Dudley Evans, \& R. Backhouse (Eds.), Economics and language (pp. 16-28). London: Routledge.

McConnell, C. R., \& Brue, S. L. (1999). Economics: Principles, problems and policies (14th ed.). Boston: McGrawHill Irwin.

McConnell, C. R., \& Brue, S. L. (2000). Economics: Principles, problems and policies (15th ed.). Boston: McGrawHill Irwin.

McConnell, C. R., \& Brue, S. L. (2005). Economics: Principles, problems and policies (16th ed.). Boston: McGrawHill Irwin.

Mohr, P., \& Fourie, L. (2000). Economics for South African students. Pretoria, South Africa: Van Schaik Publishers.

Myers, G. (1992). Textbooks and the sociology of scientific knowledge. English for Scientific Purpose, 11(1), 3-17.

Paxton, M. (2003). Ways in which students gain access to university discourses: The intersection of the academic curriculum with student voices. In C. Prichard, \& P. Trowler (Eds.), Realizing qualitative research into higher education (pp. 21-39). Aldershot: Ashgate Publishers.

Paxton, M. (2004). Intertextuality in student writing: The intersection of the academic curriculum and student voices in first year economics assignments. Unpublished doctoral dissertation, University of Cape Town, South Africa.

Paxton, M. (2006). Intertextual analysis: A research tool for uncovering the writer's emerging meaning. In L. Thesen, \& E. van Pletzen (Eds.), Academic literacies and the languages of change (pp. 84-103). London: Continuum.

Paxton, M. (2007). Students' interim literacies as a dynamic resource for teaching and transformation. Southern African Linguistics and Applied Language Studies, 25(1), 1-12.

Scollon, R., \& Scollon, S. (1981). Narrative, literacy and face in interethnic communication: Advances in discourse processes. Norwood, NJ: Ablex.

Swales, J. (1993). The paradox of value: Six treatments in search of the reader. In W. Henderson, T. DudleyEvans, \& R. Backhouse (Eds.), Economics and language (pp. 223-239). London: Routledge.

Yin, R. (1994). Case study research: Design and methods (2nd ed.). Thousand Oaks, CA: Sage Publishing. 